松島 健, 河野 道宏

東京医科大学脳神経外科

\title{
Preservation of Facial and Hearing Functions in Vestibular Schwannoma Surgery
}

\author{
Ken Matsushima, M.D., and Michihiro Kohno, M.D., Ph.D. \\ Department of Neurosurgery, Tokyo Medical University
}

Vestibular schwannomas are one of the most common types of tumor in the cerebellopontine angle. The treatment of vestibular schwannomas has evolved over several decades to the point where the main goal is no longer merely saving life through a hazardous surgical procedure : now it is possible to aim at preserving facial and/or hearing functions while achieving optimal tumor control. In order to accomplish this challenge safely, various diagnostic and/or treatment modalities have been developed, including radiological imaging, neuromonitoring, radiosurgery, and interventional radiology. Needless to say, such treatment requires much of the surgeon in terms of multiple skill sets and a wide range of knowledge, but the authors believe that a detailed knowledge of microsurgical anatomy is also essential in utilizing the plethora of treatment modalities available. In this article, the microsurgical anatomy of the cerebellopontine angle is reviewed with respect to its relevance for vestibular schwannoma surgery. Anatomical variations in the cranial nerves and vascular structures encountered intraoperatively in more than 1,200 vestibular schwannoma surgeries are introduced.

(Received October 25, 2018; accepted November 7, 2018)

Key words : acoustic neuroma surgery, cerebellopontine angle, microsurgical anatomy, retrosigmoid transmeatal approach, vestibular schwannoma

Jpn J Neurosurg（Tokyo）28：414-423, 2019

\section{はじめに}

神経鞙腫は原発性脳腫瘍の約 10\%を占めるが，その大 半は小脳橋角部に発生する聴神経腫瘍（前庭神経鞘腫） である3). 手術による摘出だけでなく, ガンマナイフを 中心とした放射線治療や，経過観察，さらには神経線維 腫症 2 型患者に対する分子標的薬等の薬物療法など，今 日ではその治療戦略は多岐にわたる。摘出術の役割も, かつての高い死亡率・合併症率の中での「救命」という
役割から,「顔面神経機能の温存」さらに「聴機能の温 存」と急速な進歩を遂げ1)，その安全性を確保すべくト ラクトグラフィーを含めた画像診断や術中脳神経モニ夕 リング, hypervascular な腫瘍に対する術前栄養血管塞栓 術など, 治療にあたり要求される技能は複雑化している.

しかし，特にこの頭蓋底深部に脳神経・血管が密集す る小脳橋角部の治療において，どのようなモダリティを 用いるにしても，変わらずその根底を支えるのは正しい 微小外科解剖の知識であろう。本稿では, 聴神経腫瘍の 
手術における顔面・聴神経の温存を目標として，小脑橋 角部の微小外科解剖と聴神経腫瘍の臨床解剖を概説した い. また，責任著者（M. K.）の 1,200 例以上の聴神経腫 瘍手術の経験より, 術中解剖のバリエーションの数例を 紹介したい。 なお，聴神経腫瘍の術前評価や手術手技， 術中モニタリング法，治療戦略に関しては，他書を参照 された(4)6)7(9)〜11)22).

\section{小脳橋角部の基本解剖}

後頭蓋窩の基本解剖の理解のための “3 のルール” を, 特に本稿では小脳橋角部の 3 つの神経血管群として紹介 する (Fig. 1 $)^{16) 20) 26)}$. 上小脳動脈は中脳を周回しつつ動 眼神経の尾側，滑車神経の正中側，三叉神経の頭側を通 り，小脳中脳裂内にて上小脳脚表面を走行した後，小脳 テント面を栄養する。前下小脳動脈 (anterior inferior cerebellar artery：AICA）は橋を周回しつつ外転神経の脇 を通過し，顔面・聴神経近傍にて meatal loop を形成し， 小脳橋裂にて中小膎脚表面を走行した後, 小脳側面を栄 養する。一方, 後下小脳動脈 (posterior inferior cerebellar artery：PICA）は延髄外側を周回しつつ下位脳神経を通 過し, 下小脳脚表面を走行し小脳延随裂内に進入し, caudal loop ・ cranial loop を形成した後に小脳後面を栄養 する，小脳動脈，脳幹，後頭蓋㝯を走行する脳神経，小 脳脳幹裂，小脳脚，そして小脳半球面は上記のように 3 つのグループとして考えると理解しやすく，またこれら は 3 つの神経血管圧迫症候群（三叉神経痛，片側顔面㾏 攣, 舌咽神経痛) の病態理解に役立つ ${ }^{20)}$.

後頭蓋窩静脈も流出路により galenic group ・ petrosal group・tentorial groupの 3 つに分けられるが, petrosal groupの主をなす上錐体静脈（superior petrosal vein）の 分枝は, 上記 3 つの神経血管群を横断するように小脳橋 角部を走行している (Fig. 1B， C $)^{15)}$. 小脳延髄裂内の vein of cerebellomedullary fissure も流入する vein of cerebellopontine fissure が小脳橋裂を走行し, 小脳中脳裂か らの pontotrigeminal vein などと合流し，上錐体静脈を形 成する。

\section{聴神経腫瘍手術のための神経解剖}

顔面・聴神経は，橋外側下部より小脳橋角部中央を横 走し内耳道へと走行する (Fig. 1C，2A)，後方からの術 野では顔面神経は聴神経の腹側に隠れているが，膨らん だ橋下部からの起始部は小脳片葉および脈絡叢を指標に みつけることができる (infrafloccular approach ; Fig. 1C).
大型聴神経腫瘍では内減圧を先行させることも多いが, 小脳片葉および脈絡叢と下位脳神経を腫瘍の尾側より剝 離することで顔面神経起始部を同定し，早期に持続モ二 タリングを開始することが，安全な腫瘍摘出に重要と考 える (Fig. 1D-F).

顔面神経と聴神経の間には涙腺・鼻腺への分泌や味覚 を担う中間神経が走行する (Fig. 2A)。特に小型の聴神 経腫瘍手術中には腫瘍剝離中に中間神経を確認できるこ とも多い(Fig. 2C). 内耳孔近傍では聴神経は蝸牛および 上下前庭神経の 3 本に明瞭に区別される。内耳道底は transverse crest により上下に，その上方は Bill's bar によ り前後に隔てられており，顔面神経は前上方，蝸牛神経 は前下方，上前庭神経は後上方，下前庭神経は後下方に 位置する（Fig. 2B）。聴神経腫瘍は前庭神経に由来する ものが大半であり，これらの位置関係により顔面神経は 腹側上方に，螖牛神経は尾側に圧排されていることが多 い(Fig. 2D)，聴神経腫瘍手術においてわれわれが中頭 蓋窩経由法を好まないのは，上方に圧排された顔面神経 越しの腫瘍摘出を避けるためである。ただし，まれでは あるが顔面神経が背側に走行し外側後頭下到達法では腫 瘍の手前を走行していることもあるため，注意が必要で ある $(\text { Fig. 2E })^{24)}$ 。近年では拡散テンソル画像や 3D-CISS 画像を中心に神経走行の術前診断が発達しているが，そ れらの MRI 画像を根拠に手術アプローチを変更するに はまだ精度が不十分と考えている。

これらの神経群の正中側には橋延髄移行部より起始し た外転神経が Dorello 管へと上行しており，聴神経腫瘍 摘出の際にはほぼ全例で視認される。大型聴神経腫瘍で は腫瘍の正中側で圧排されていることも多く，粗暴な剝 離を行うと一過性複視を招くこともある。通常は左右 1 本ずつの外転神経であるが，1本で起始し 2 本に分かれ ることも，2 本で脳幹を起始することもあり，注意が必 要である (Fig. 2F).

聴神経腫瘍摘出は腫瘍表面の 2 重くも膜の剝離から開 始するが, そもそも聴神経腫瘍がくも膜下腫瘍かくも膜 外腫瘍かはいまだに議論の分かれる点であ

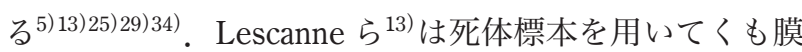
下腔が内耳道底まで存在することを証明しており，著者 $ら^{5)}$ も聴神経腫瘍 118 例を検討し，その多くがくも膜下 腫瘍であることを光学显微鏡および電子顕微鏡を用いて 報告した。

\section{聴神経腫瘍手術のための血管解剖}

AICA や PICA は相補的に解剖学的バリエーションの多 

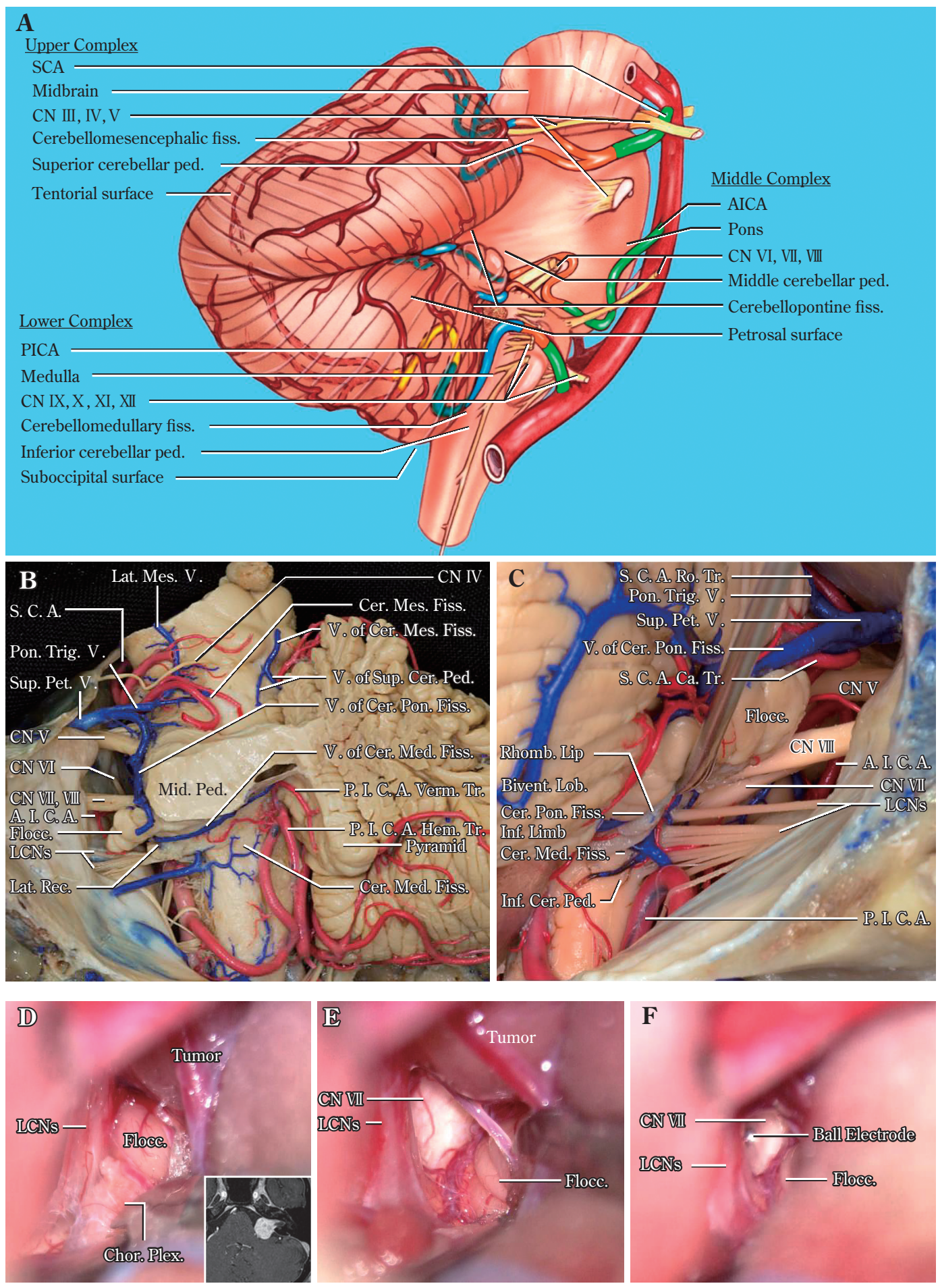

Fig. 1 “Rule of 3" in posterior fossa and identification of root exit zone of CN VII

A, B : Three neurovascular complexes in the posterior fossa. In the middle neurovascular complex, the AICA originates from the basilar artery, encircles the pons near CN VI, makes the meatal loop around CNs VII and VIII, courses along the middle cerebellar peduncle around the cerebellopontine fissure, and terminates by supplying the cerebellar petrosal surface (A : reproduced from the Rhoton Collection [http://rhoton.ineurodb.org]; B : modified with permission from Matsushima et al. ${ }^{16)}$ ).

$\mathrm{C}$ : The flocculus and choroid plexus are used as landmarks to identify the root exit zone of $\mathrm{CN}$ VII in the right cerebellopontine angle (modified with permission from Matsushima et al. ${ }^{16)}$ ).

D-F : At the initial stage of the tumor removal in vestibular schwannoma surgery, the flocculus was dissected from the lower $\mathrm{CNs}$ and the tumor (E), after which a ball-type stimulating electrode was placed on $\mathrm{CN}$ VII for the continuous facial nerve monitoring. 

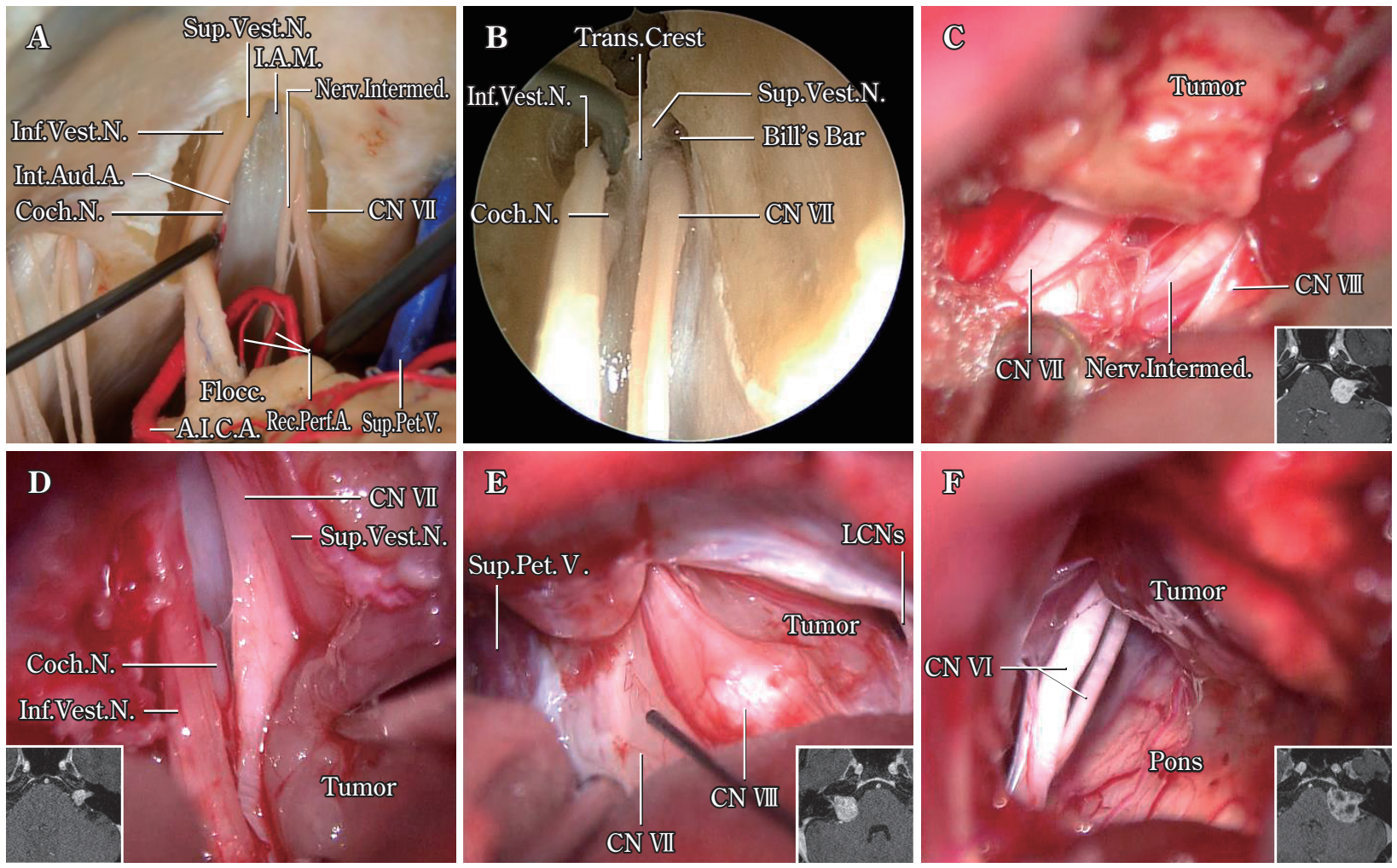

Fig. 2 Cranial nerves around cerebellopontine angle

A : In the left cerebellopontine angle, CNs VII and VIII arise at the lateral end of the pontomedullary sulcus behind the flocculus, and course into the internal acoustic meatus.

B : Angled endoscopic view of the 4 nerves around the fundus of the internal acoustic meatus separated by the transverse crest and Bill's bar (modified with permission from Matsushima et al. ${ }^{17)}$ ).

C : A developed nervus intermedius was carefully dissected from the tumor.

D : The vestibular schwannoma originated from the superior vestibular nerve. The facial nerve was displaced anterosuperiorly, cochlear nerve displaced anteroinferiorly, and the inferior vestibular nerve displaced posteroinferiorly. All were dissected precisely from the tumor and preserved.

E : The facial nerve is rarely displaced dorsally and it disturbs the tumor removal. The superior petrosal vein is usually displaced cranially as seen in this case.

F : The duplicated CN VI was dissected carefully from the medial surface of the tumor.

い血管であるが，聴神経腫瘍手術で最も注意すべき動脈 はAICA とその分枝である. AICA は脳底動脈より起始し 内耳孔近傍にて meatal loop を形成した後, 小脳側面を栄 養する（Fig. 1A，2A）。この meatal loop は硬膜もしくは 非常にまれには骨内へと埋没していることもあり, 可動 性を確保するために硬膜剝離や骨削除を要することがあ る (Fig. 3A-C $)^{31) 33)}$ 。 また, meatal loop が内耳道内へと 深く進入している場合には loop が腫瘍と内耳道壁で固 定されていることもあり, 十分な内減圧の後に慎重な剥 離を要する $(\text { Fig. 3D-F })^{33)}$.

AICA の meatal loop 近傍からは内耳動脈 (internal auditory artery, labyrinthine artery）を subarcuate artery（弓 下動脈), 反回穿通動脈が分枝する (Fig. 2A, Fig. 4)。内 耳動脈は $1 \sim 2$ 本ほど存在することが多く, 内耳道内に
て各脳神経や硬膜, 骨膜を栄養した後, 前庭および蝸牛 へと分枝する (Fig. 4C-E ${ }^{14) 20221)}$. 内耳動脈が聴神経腫 瘍術中に視認できることはまれではあるが, 内耳道内も しくは近傍にて確認できた場合には可能なかぎり温存し ている (Fig. 4F)。 また, 術中モニタリングで振幅の低下 を認め，手技に伴う血管攣縮が疑われた場合には塩酸パ パベリンを用いることもある。一方, 通常 1 本の subarcuate artery は meatal loop 近傍より内耳道後上方の硬膜を 貫通し subarcuate fossa（弓下窩）へと進入し半規管など を栄養する (Fig. 4A $)^{14) 20221)}$ 。聴神経腫瘍手術の際には, 腫瘍剝離初期の段階で subarcuate artery は切断を要する ことが多いが，それに伴う聴力低下は経験していない (Fig. 4B)。通常, 内耳動脈は meatal loop の近位側にて, subarcuate artery は遠位側にて分枝しており, subarcuate 

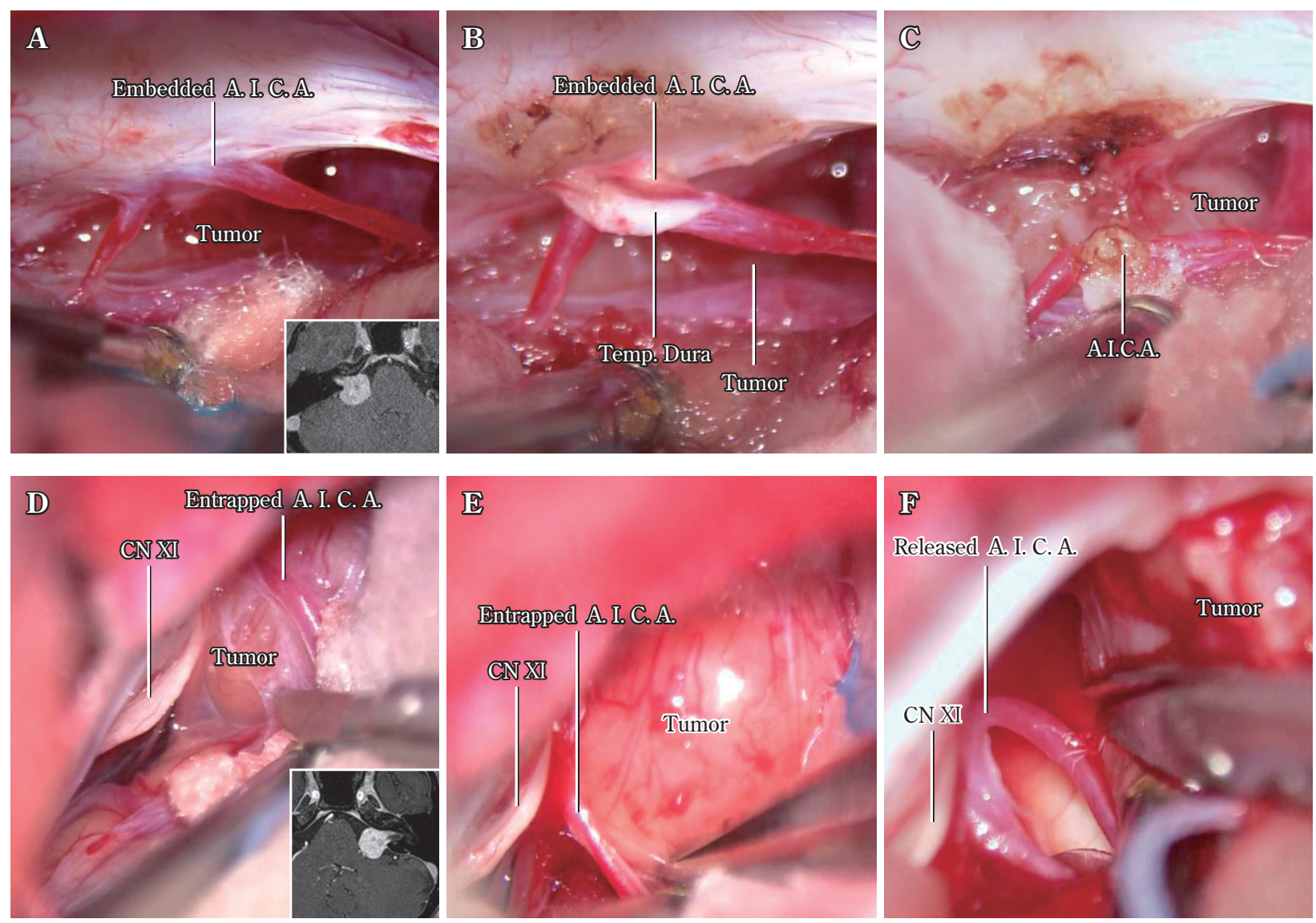

Fig. 3 Anatomical variations of AICA in vestibular schwannoma surgery

A-C : The embedded AICA (A) was released by dissecting the surrounding dura (B, C).

D-F : The meatal loop reached deeply inside the internal acoustic meatus, and the loop was entrapped by the posterior wall of the meatus and the tumor extending into it (D, E). Adequate internal decompression enabled release and mobilization of the loop $(\mathbf{F})$.

artery は腫瘍剝離の初段階で腫瘍後面（外側後頭下到達 法での手前）に確認できることが多い. また，この他に 小脳片葉や脳幹への反回穿通動脈も分枝しているため, meatal loopを移動させる前には十分な観察が必要である.

内耳道底にて transverse crest の上方, Bill's bar の前方 より顔面神経管に進入した顔面神経は側頭骨内を走行し 膝神経節（geniculate ganglion）を形成した後に顔面神経 管内を下行し茎乳突孔へと至る。この間, 内耳動脈だけ でなく, 外䅡動脈系より中硬膜動脈 (middle meningeal artery）の petrosal branch（錐体枝）や superior tympanic artery, 後耳介動脈（posterior auricular artery）もしくは 後頭動脈 (occipital artery) の stylomastoid branch（茎乳 突枝), 上行咽頭動脈 (ascending pharyngeal artery) の neuromeningeal branch などからも栄養される ${ }^{2) 12)}$. 特に superior tympanic artery と stylomastoid branch は血管撮 影において顔面神経管の走行を示し, facial arcade とも呼 ばれる2)12)。これらの血管は小脳橋角部髄膜腫の栄養血.
管としても有名であり，術前塞栓術の際には神経症状の 出現・増悪に注意が必要である ${ }^{30)}$. また, hypervascular な聴神経腫瘍の多くは, 椎骨脳底動脈系からの豊富な血 流を受けるが，これらの外頝動脈系の分枝からも血流を 受けていることが多く, 詳細な術前評価が必要である $\left(\right.$ Fig. 4G) ${ }^{32)}$.

聴神経腫瘍を含めた小脳橋角部手術において最も注意 すべき静脈は上錐体静脈である（Fig. 5)。上錐体静脈は 脳幹前面からの transverse pontine vein や小脳中脳裂か らの pontotrigeminal vein な゙多数の静脈の合流により形 成されるが, その最大の分枝は小脳側面からの vein of cerebellopontine fissureであり，これは第四脳室を走行す る vein of cerebellomedullary fissureからも還流を受け $3^{15) 19)}$. 上錐体静脈は内耳孔上方にて上錐体静脈洞へと 合流するが，その位置により medial, intermediate, lateral type に分類される ${ }^{15) 19)}$. 多くの症例において, 上錐 体静脈は腫瘍の頭側から正中側（脳幹側）に圧排されて 

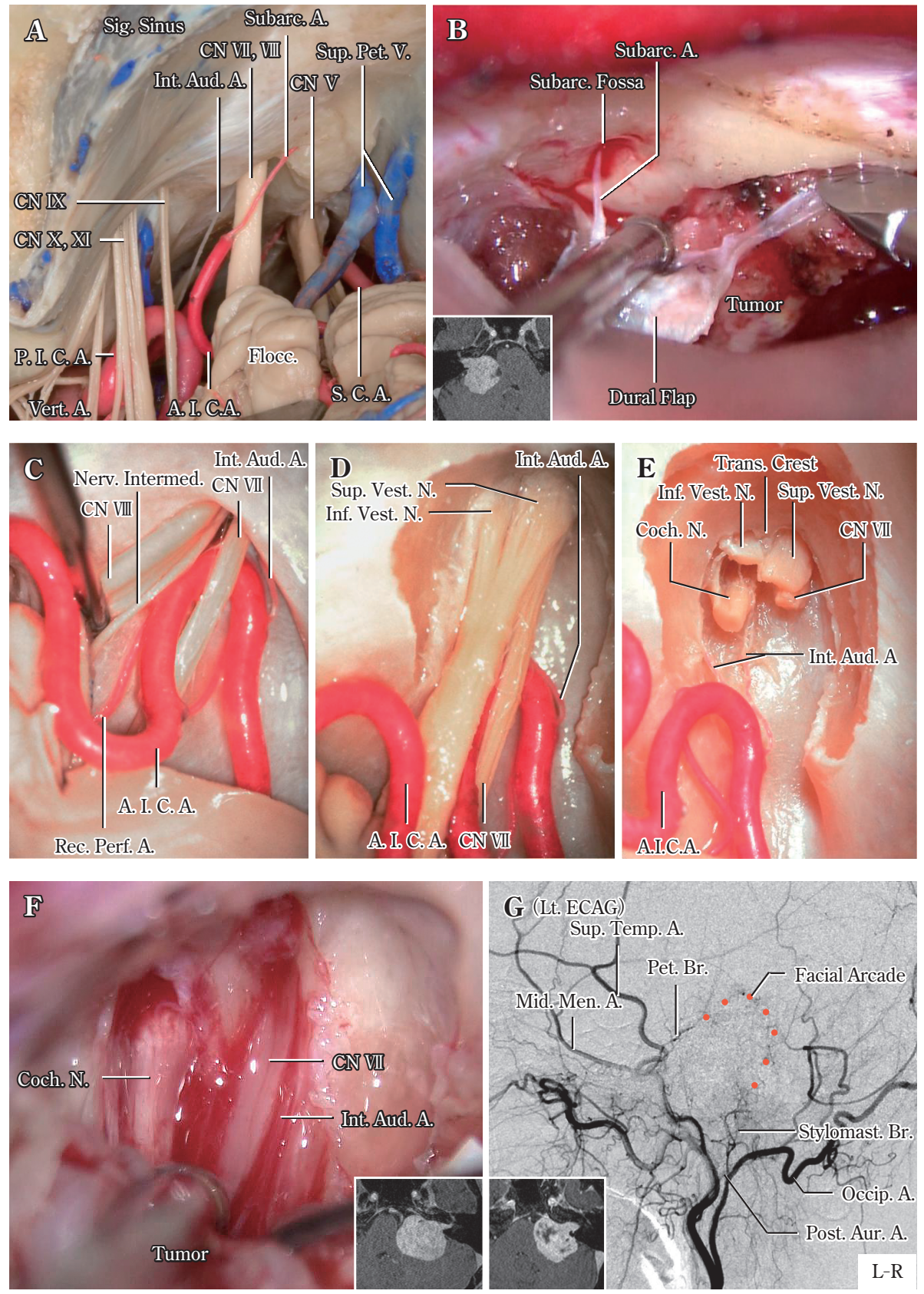

Fig. 4 Branches from AICA's meatal loop

A : In the left cerebellopontine angle, the subarcuate and internal auditory (labyrinthine) arteries originate from around the meatal loop of AICA, and course into the subarcuate fossa and internal acoustic meatus respectively (modified with permission from Matsushima et al. $\left.{ }^{17}\right)$.

B : The subarcuate artery was exposed to divide when the dura posterior to the meatus was dissected for the transmeatal approach.

C-E : The internal auditory artery courses into the internal acoustic meatus to supply the nerves, meatal dura, and labyrinth structures. The recurrent perforating artery bifurcates from the meatal loop of AICA, and supplies the flocculus and brainstem (modified from Matsushima ${ }^{20)}$ ).

F : The internal auditory artery was identified in the internal acoustic meatus during dissection of the intrameatal tumor.

G : Preoperative external carotid angiogram of a hypervascular vestibular schwannoma supplied by the AICA, petrosal branch of the middle meningeal artery, and stylomastoid branch of the occipital artery. The developed petrosal and stylomastoid branches, the major branches suppling the facial nerve, formed the facial arcade (red dotted line). 

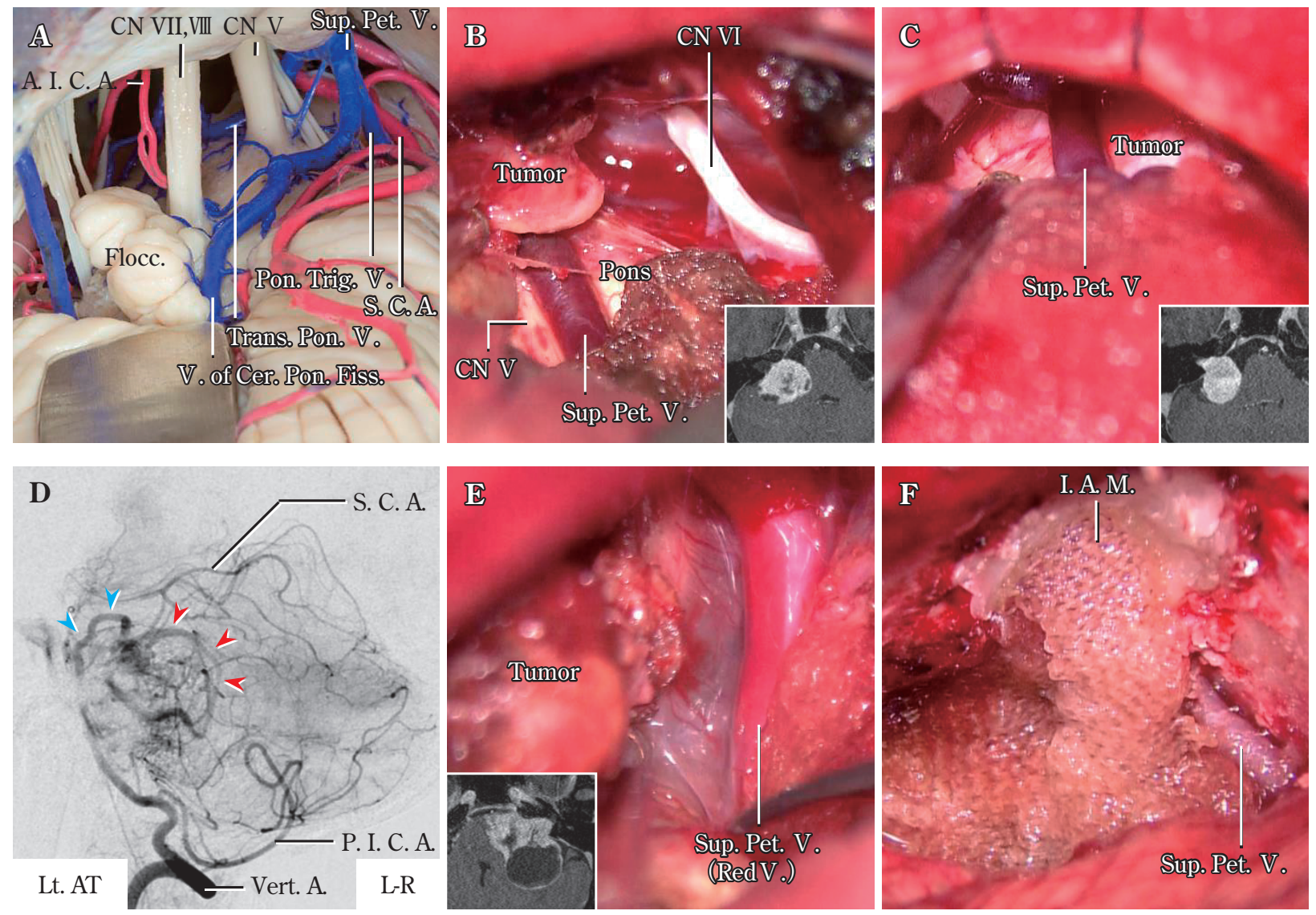

Fig. 5 Superior petrosal vein

A : The superior petrosal vein, the largest vein in the posterior fossa, empties into the superior petrosal sinus after formed by multiple tributaries, including the vein of the cerebellopontine fissure, transverse pontine vein, and pontotrigeminal vein (modified with permission from Matsushima et al. ${ }^{15)}$ ).

B : The superior petrosal vein (medial type) was displaced ventrally to the tumor and dissected from the tumor at the final stage of the tumor removal.

C : The superior petrosal vein (lateral type) was displaced dorsally to the tumor and disturbing the tumor removal at the initial stage of the tumor exposure.

D-F : A case of the hypervascular vestibular schwannoma with an AV shunt. The developed superior petrosal vein (vein of the cerebellopontine fissure : red arrowheads and transverse pontine vein : blue arrowheads) was seen in arterial phase of the preoperative vertebral angiogram (D). The vein of the cerebellopontine fissure was identified as a red vein at the initial stage of the surgery (E). Its color was changed from fresh red to dark following tumor removal $(\mathbf{F})$.

おり, 剝離初段階の 2 重くも膜剝離の際に頭側に移動さ せることが可能である (Fig. 2E). また，まれではある が, 腹側に压排されており, 背側からの腫瘍摘出の妨げ にはまったくならないこともある（Fig. 5B）。しかし， 内耳孔より背側もしくは横静脈洞 $-\mathrm{S}$ 状静脈洞合流部近 傍にて静脈洞へと合流する場合（lateral type）には，硬 膜切開後の不用意な小脳牽引で出血をきたしたり, 腫瘍 表面を上錐体静脈が走行しており静脈越しの腫瘍摘出が 必要となることもある(Fig. 5C). また動静脈シャントを 形成するような hypervascularな聴神経腫瘍においては, 上錐体静脈が red vein となっていることもあり慎重な剝
離を要する（Fig. 5D-F）.

再発を防ぐためには聴神経腫瘍の内耳道内成分は十分 な摘出が必要と考えており, 頭尾側に内耳道硬膜を 180 度露出する深く広い内耳道削除を行っている (Fig. 4F). 内耳道削除の際に注意すべき解剖学的構造物は外側に位 置する半規管と，ときに尾側に存在する高位頝静脈球 (high jugular bulb)である。これらの位置関係は腫瘍によ る内耳道破壊の程度によっても異なり, 必ず術前に側頭 骨 CT にて削開部位の計測を行うようにしている ${ }^{22)}$. ま た, 高位頚静脈球が術野の妨げとなる場合には, 頝静脈 球上壁を露出し, 凝固縮小もしくは骨蝋で押し下げるこ 

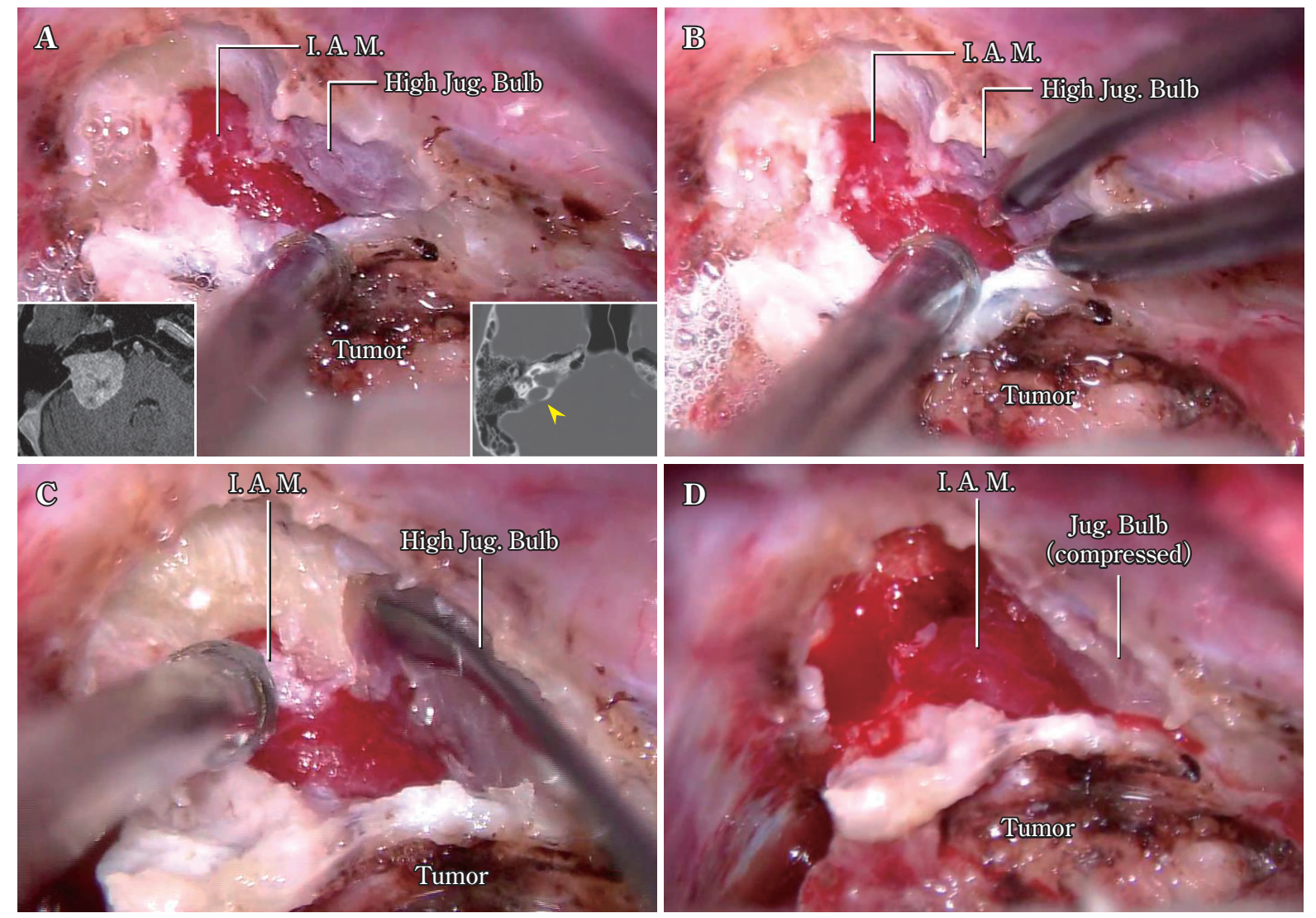

Fig. 6 Management of high jugular bulb

During drilling of the posterior wall of the internal acoustic meatus, a high jugular bulb (yellow arrowhead on CT scan) was exposed (A). It was shrunk by bipolar coagulation (B), and compressed with bone wax (C). It was done in order to accomplish wide drilling of the internal acoustic meatus (D).

とで十分な術野を確保する $(\text { Fig. 6 })^{28)}$.

\section{顔面神経機能・聴力温存のために}

本稿では聴神経腫瘍手術およびその術前評価や hypervascular な腫瘍に対する術前塞栓術を念頭に正常解剖と 術中解剖を概説したが，顔面神経機能および聴力温存の ためには，正しい治療戦略の選択（手術適応の検討）と 術中モニタリング, 手術手技も必要となる。「持続顔面神 経モニタリングや電気化した剝離子の使用」,「7つの進 入口」, 前庭神経の perineurium を含む tumor capsule を 温存する subcapsular (subperineurial) dissection ${ }^{27}$ などの 「㔀離の 3 プレーン」,「腫瘍の串刺しと持ち上げ」など, 他書を参照していただきたい(4)67)99～11). 大きい囊胞性腫 瘍における突発型の後迷路障害性聴力低下例では手術に よる聴力改善例も報告しており ${ }^{8)}$, 今後は機能温存だけ でなく機能改善にも期待したい. 一方で, 聴力温存術後 患者の長期経過における聴力低下も報告されており ${ }^{23)}$,
われわれも同様の聴力低下を経験することがある。 ま た，両側聴神経腫瘍を主徵とする神経線維腫症 2 型患者 の腫瘍制御と機能温存は孤発例以上に難渋することが多 い ${ }^{18)}$ 。より多くの聴神経腫瘍患者の顔面神経機能・聴力 温存のためにはさらなる研鑽と経験の蓄積が必要と考え る.

\section{まとめ}

聴神経腫瘍の手術における顔面・聴神経の温存を目標 として, 小脳橋角部の微小外科解剖および聴神経腫瘍の 手術解剖を概説し, 術中に遭遇する解剖学的バリエー ションの数例を紹介した。顔面神経機能温存, さらには 聴力温存と治療目標の向上にあわせ, 術前診断や術中脑 神経モニタリングを含めたさまざまな技能が要求される 疾病であるが，その根底を支えるのは詳細な正常解剖の 知識とそれを基盤とした臨床解剖の把握と考元る。外科 手術を担う先生方はもちろん，放射線治療や血管内治療 
を担う先生方も含め, 本稿が少しでも多くの読者の参考 になれば幸いである。

本論文の一部は第 38 回日本脳神経外科コングレス総会 （2018 年 5 月 19 日，大阪）において発表した.

著者全員は日本脳神経外科学会への COI 自己申告の登録を 完了しています。

本論文に関して開示すべきCOI はありません.

\section{文 献}

1) Akard W, Tubbs RS, Seymour ZA, Hitselberger WE, CohenGadol AA : Evolution of techniques for the resection of vestibular schwannomas : from saving life to saving function. $J$ Neurosurg 110:642-647, 2009.

2) Blunt MJ : The blood supply of the facial nerve.J Anat 88 : 520-526, 1954

3) Brain Tumor Registry of Japan (2001-2004). Neurol Med Chir (Tokyo) 54 (Suppl) : 1-102, 2014.

4）河野道宏：神経䩪腫：モニタリングの進歩. 脳外速報 20:1154-1161, 2010.

5) Kohno M, Sato H, Sora S, Miwa H, Yokoyama M: Is an acoustic neuroma an epiarachnoid or subarachnoid tumor? Neurosurgery 68: 1006-1016, 2011.

6) 河野道宏: 聴神経腫瘍手術一手術適応と機能温存一, 脳 外誌 $23: 20-28,2014$.

7）河野道宏：聴神経腫㿟手術におけるトラブルへの対応. 脳外速報 24:24-33, 2014 .

8) Kohno M, Sora S, Sato H, Shinogami M, Yoneyama H : Clinical features of vestibular schwannomas in patients who experience hearing improvement after surgery. Neurosurg Rev 38: 331-341, 2015.

9）河野道宏：Retrosigmoid approach。伊達 勲編：新 NS NOW 2 若手脳神経外科医が経験したい手術アプローチ. 東京，メジカルビュー社，2015，pp.110-121.

10）河野道宏：神経鞘腫 特に神経との剝離に重点をおいて。 森田明夫編：新 NS NOW 4 脳・脊髄腫瘍摘出のための 引き出し. 東京, メジカルビュー社, 2015, pp.126-135.

11）河野道宏：聴神経腫瘍・小脳橋角部腫瘍の治療一手術を 中心に一. 脳外誌 $26: 430-435,2017$.

12）小宮山雅樹：詳細版 脳脊随血管の機能解剖. 大阪, メ ディカ出版, 2011.

13) Lescanne $\mathrm{E}$, Velut $\mathrm{S}$, Lefrancq $\mathrm{T}$, Destrieux $\mathrm{C}$ : The internal acoustic meatus and its meningeal layers: a microanatomical study.J Neurosurg 97:1191-1197, 2002.

14) Martin RG, Grant JL, Peace D, Theiss C, Rhoton AL Jr : Microsurgical relationships of the anterior inferior cerebellar artery and the facial-vestibulocochlear nerve complex. Neurosurgery 6:483-507, 1980.

15) Matsushima K, Matsushima T, Kuga Y, Kodama Y, Inoue K, Ohnishi H, Rhoton AL Jr: Classification of the superior petrosal veins and sinus based on drainage pattern. Neurosurgery 10 Suppl 2 : 357-367, 2014.

16) Matsushima K, Yagmurlu K, Kohno M, Rhoton AL Jr : Anatomy and approaches along the cerebellar-brainstem fissures.J Neurosurg 124: 248-263, 2016.

17) Matsushima K, Komune N, Matsuo S, Kohno M : Microsurgical and endoscopic anatomy for intradural temporal bone drilling and applications of the electromagnetic navigation system : various extensions of the retrosigmoid approach. World Neurosurg 103: 620-630, 2017.

18）松島 健, 河野道宏：NF2 聴神経腫場の治療選択：外科 治療の立場から. No Shinkei Geka 47:161-167, 2019.

19) Matsushima T, Rhoton AL Jr, de Oliveira E, Peace D : Microsurgical anatomy of the veins of the posterior fossa. $J$ Neurosurg 59:63-105, 1983.

20）松島俊夫：後頭蓋窩の微小外科解剖と手術 後頭蓋窩の 微小外科解剖と手術。東京, サイメッド・パブリケー ションズ, 2006.

21) Mazzoni A, Hansen CC: Surgical anatomy of the arteries of the internal auditory canal. Arch Otolaryngol $91: 128-135$, 1970.

22）中島伸幸, 河野道宏: 小脳橋角部腫瘍に対する開頭術. No Shinkei Geka 45 : 451-467, 2017.

23) Nakamizo A, Mori M, Inoue D, Amano T, Mizoguchi M, Yoshimoto K, Sasaki T : Long-term hearing outcome after retrosigmoid removal of vestibular schwannoma. Neurol Med Chir (Tokyo) 53: 688-694, 2013.

24) Nejo T, Kohno M, Nagata O, Sora S, Sato H : Dorsal displacement of the facial nerve in acoustic neuroma surgery : clinical features and surgical outcomes of 21 consecutive dorsal pattern cases. Neurosurg Rev $39: 277-288,2016$.

25）大畑建治, 永井健司, 森野道晴: 聴神経腫崵の手術法一 小脳橋角部におけるクモ膜外発育についての概念とその 応用一. Neurosurgeons 15:159-165, 1996.

26) Rhoton AL Jr: Cranial Anatomy and Surgical Approaches. Philadelphia, Lippincott Williams \& Wilkins, 2003.

27) Sasaki T, Shono T, Hashiguchi K, Yoshida F, Suzuki SO : Histological considerations of the cleavage plane for preservation of facial and cochlear nerve functions in vestibular schwannoma surgery. J Neurosurg 110:648-655, 2009.

28) Shao KN, Tatagiba M, Samii M: Surgical management of high jugular bulb in acoustic neurinoma via retrosigmoid approach. Neurosurgery $32: 32-36,1993$.

29）田中雄一郎, 及川 奏, 小林茂昭：Lateral Suboccipital Approach一解剖学的所見に基づいた聴神経鞘腫の手術手 技一. 松野治雄編: 顕微鏡下手術のための脳神経外科解 剖 XI一手術アプローチの微小外科解剖一, 東京, サイ メッド・パブリケーションズ, 1999, pp.197-206.

30) Tanaka Y, Hashimoto T, Watanabe D, Okada H, Kato D, Aoyagi S, Akimoto J, Kohno M : Post-embolization neurological syndrome after embolization for intracranial and skull base tumors : transient exacerbation of neurological symptoms with inflammatory responses. Neuroradiology $\mathbf{6 0}$ : 843-851, 2018.

31) Tanriover N, Rhoton AL Jr: The anteroinferior cerebellar artery embedded in the subarcuate fossa : a rare anomaly and its clinical significance. Neurosurgery $\quad 57: 314-319$, 2005.

32) Teranishi $Y$, Kohno M, Sora S, Sato H, Nagata $\mathrm{O}$ : Hypervascular Vestibular Schwannomas: Clinical Characteristics, Angiographical Classification, and Surgical Considerations. Oper Neurosurg (Hagerstown) 15:251-261, 2018.

33) Yamakami I, Kubota S, Higuchi Y, Ito S : Challenging anterior inferior cerebellar artery in retrosigmoid vestibular schwannoma removal. World Neurosurg 121 : e370-e378, 2019.

34) Yasargil MG, Smith RD, Gasser JC : Microsurgical approach to acoustic neurinomas. Adv Tech Stand Neurosurg $\quad 4: 93^{-}$ 129, 1977. 
旨

聴神経腫瘍の手術における顔面・聴神経の温存

松島健河野 道宏

聴神経腫瘍の治療戦略は多岐にわたり, その中で摘出術の役割も, かつての「救命」から「顔面神 経機能の温存」さらに「聴機能の温存」と急速な進歩を遂げ, 手術にあたり要求される技能は複雑化 している. しかし, 特にこの頭蓋底深部に脳神経・血管が密集する小脳橋角部の治療において, 变わ らずその根底を支えるのは正しい微小外科解剖の知識とそれを基盤とした臨床解剖の把握と考える. 本稿では, 恥神経腫場手術における顔面・聴神経の温存を目標として, 小脳橋角部の微小外科解剖お よび聴神経腫瘍の臨床解剖を概説した.

脳外誌 $28 ： 414-423,2019$ 